\title{
Enhancing Potential for Integrated Catchment Management in New Zealand: a multi-scalar strategic perspective
}

\author{
Ali Memon, Brett Painter and Edward Weber*
}

*Ali Memon is with the Environmental Management Department, Environment, Society and Design Faculty of Lincoln University, New Zealand. Brett Painter is with Lincoln Environmental Research at Lincoln Ventures Ltd, New Zealand. Ed Weber is with the Department of Political Science, Washington State University, U.S.A. Email: memona@lincoln.ac.nz.

Abstract: An integrated approach to natural resource management at the catchment scale in a collaborative manner is a strong theme in the recent environmental management and planning literature. In New Zealand, integrated water resource management is undertaken by regional councils within the framework of a devolved legislative mandate, the Resource Management Act 1991 (RMA). For some time these councils have experienced difficulties discharging this role effectively, in particular with respect to the catchment scale. We argue for a multi-scalar national policy framework, encapsulating bottom-up and top-down water governance strategies, in order to enhance the potential of ICM.

Keywords: New Zealand, Resource Management Act, Integrated Catchment Management, ICM Appraisal; Multi-scalar perspective; Water.

\section{Introduction}

Water resource management authorities globally are increasingly adopting regional ecosystem approaches and reflexive governance as pathways to sustainable development (Paton et al 2004; Vos et al 2006). An integrated collaborative approach to natural resource management at the catchment scale within a multi-scalar institutional setting is a strong theme in the recent literature (e.g., Lovell et al. 2002; Painter \& Memon 2008). New Zealand's Resource Management Act (RMA), enacted in 1991, is a devolved planning mandate for integrated natural resource management exercised by elected regional councils. The territorial jurisdiction of regional councils established in 1988 was purposely defined on the basis of groups of large water catchments (including groundwater aquifers) to facilitate an integrated approach to natural resource management. Integrated management of water 
allocation, water quality and related land management are primary functions of regional councils. However, regional councils have shied away from exercising their devolved integrated water planning mandate at the sub-regional catchment scale. Instead, provisions of first generation regional water plans tend to be framed region-wide in scope. In some plans, water quality and quantity issues are addressed separately with limited linkages, a reflection of poor integration.

Growing cognisance of planning at the catchment scale is a recently re-emergent phenomenon under the RMA planning regime ${ }^{1}$. The community engagement and strategic planning provisions of the new Local Government Act 2002 (LGA) ${ }^{2}$ and the 2005 RMA amendments ${ }^{3}$, embedded in a wider cultural shift from government to governance, are improving the potential for integrated water resource management with community engagement ${ }^{4}$. A need for a greater catchment focus has become increasingly evident during the last decade for a number of reasons: to respond to potential adverse impacts on land and water connected with intensification and expansion in the farming sector; growing water demand and conflict between in-stream and out-of stream water users; dissatisfaction with predominantly top-down hierarchical approaches by regional councils to address these concerns; and demands by Māori, the indigenous inhabitants, to be actively involved in governance of water resources. These forces exemplify characteristics of a 'wicked' environmental problem (e.g., Weber \& Khademian 2008a) and have precipitated a gradually widening appreciation of integrated collaborative planning of land and water resources at a catchment scale.

The objective of this paper is to interrogate challenges for integrated catchment management (ICM) in New Zealand under the RMA regime from a multi-scalar perspective and to suggest possible ways forward. It builds on recent social science research on ICM in New Zealand (Parkes \& Panelli 2001; Bowden, 2002; Tipa \& Welch, 2006; Fenemor et al. 2008; Memon \& Weber 2008). Apart from economics, the 'human dimension' of ICM research is not as well established or recognised in New Zealand as well as bio-physical research is. There is a need for improved social understanding of catchment governance focussed on context, perceptions and interrelationships amongst and between

\footnotetext{
${ }^{1}$ A focus on catchment based planning by Catchment Boards, as special purpose ad hoc authorities, was more evident under the Water and Soil planning regime preceding the adoption of the RMA planning regime in 1991. The individual Catchment Boards were amalgamated into larger Regional Councils in 1988.

${ }^{2}$ The LGA 2002 empowers local authorities to promote sustainable well-being of communities.

${ }^{3}$ The amendments made to the RMA in 2005 re-affirm the role of regional councils to take a strategic planning approach to allocation and management of water resources.

${ }^{4}$ The term governance connotes a shift from conventional modes of governing by central government to new modes that rely more extensively on input of different levels of government, private actors, firms and non government organisations and on soft policy instruments (see Scholz and Stiftel, 2000).
} 
user groups, communities, regulators and other stakeholders and the environments from place based, multi-scalar perspectives. We hope this paper will contribute to that.

The paper is based on analysis of data from primary and secondary sources. The primary sources include three sets of qualitative in-depth, key-informant interviews that were conducted between November 2007 and March 2009. The first set of interviews was with eight respondents with professional and political roles related to water resource planning in Canterbury, a South Island region which is experiencing deep-seated conflicts over water allocation and quality. The purpose of these interviews was to explore to what extent the Canterbury Regional Council had been successful in delivering on its mandate of integrated water management and the barriers which were faced. The second set of interviews was with six environmental professionals with significant involvement in recent ICM initiatives in the South Island of NZ. These individuals had initiated and led ICM projects during the last few years ${ }^{5}$. Our objective in these interviews was to identify institutional and related factors which had contributed to the success of these initiatives or posed barriers. The third set of seven interviews focussed on exploring the causes of the 'science impasse', which was one of key factors we had identified dominating water management conflicts in central Canterbury. The respondents interviewed were an Environment Court Judge, senior officials in the Canterbury Regional Council, environmental consultants who had worked for different parties and an environmental NGO.

Respondents were promised confidentiality. Interviews lasted approximately an hour each and were conducted by a team of two or three researchers. The interview transcripts and notes were reviewed after each interview and then were content analysed to highlight key themes through a process of triangulation. The interview narratives provided us with a valuable data source in addition to documentary data and the insights developed from long standing role as observers of the Canterbury situation by two of the three authors. Secondary sources of data include examination of relevant legislation, plans, conference proceedings and research reports and discussion transcriptions of the Selwyn Water Allocation Liaison Group in Canterbury ${ }^{6}$.

\footnotetext{
${ }^{5}$ The key ICM initiatives discussed were Motueka, Waihora-Ellesmere, Orari, Waitaki, Kakanui and Taieri catchments and catchments in North Otago.

${ }^{6}$ The Selwyn Water Allocation Liaison Group was formed to test how a research team and local water stakeholders could best collaborate in a 'lawyer free zone', while many participants were also actively involved in legally driven, adversarial water management processes.
} 
The paper is organised as follows. The broader conceptual context is presented first, followed by an analysis of challenges to ICM within the RMA planning regime and means to enhance ICM's potential.

\section{The Broader Context}

An integrated socio-ecological systems approach to sustainable development is imperative because the underlying causes of many bio-physical environmental problems can be traced back to ways humans interact with our highly inter-connected Earth System (Gunderson \& Holling 2002). ICM, and allied concepts such as integrated coastal management (Olsen 2003), are means to operationalise integrated management within particular geographical contexts. A defining feature of these concepts is their focus on adaptive governance of natural resources in order to address needs for both economic development and conservation in geographically specific places while also embracing socio-ecological knowledge (including local knowledge) and uncertainties. Thus, ICM may be conceptualised as a multi-layered systems approach to water management (Warner, 2007).

Seen from a related perspective, management of water as a common pool resource is a collective action problem and dialogue amongst actors is seen as an imperative for integrated management (Stiftel \& Scholz 2005; Gray 2005; Weber 2003). Recent literature suggests that informed, deliberative engagement with stakeholders of place, interest and regulation can discover common ground, create ownership in joint decisions, and increase trust, with resulting benefits in the sustainable use and management of natural resources (e.g., Ostrom 1990; Kates et al. 2001; Weber 2003). Viewed from this perspective, normal science on its own has failed to resolve "wicked" environmental problems such as non-point source water pollution. There is a manifest need to widen the scientific basis of ICM to include alternate ways of understanding nature-society relations (Brueckner \& Horwitz 2005; Brand \& Kervonen 2007).

Building successful collaborative capacity for the sake of sustainable communities, however, is not easy to do (e.g., see Curtis 2000; Rydin \& Pennington 2000; Castree 2008). There is wide agreement that the effectiveness of a collaborative approach is contingent on having in place appropriate institutional arrangements that take into account the nature of the problem as well as the social, economic, cultural and political contexts (e.g., Hanna et al. 1996; Verma 2007; Sick 2008). The social science usage of the term 'institutional arrangements' in this context encompasses formal rules (such as statutes) as well as informal norms, roles and operating practices that govern human behaviour and that are so stable, structured and accepted that they can be said to be 'institutionalised' (Dovers 2001). 
At the local level, the institutional attributes of an ICM approach considered most likely to achieve positive progress are:

- $\quad$ inclusiveness (Daniels \& Walker 2001);

- formal binding collective choice rules with a purpose: promoting fairness, equity, continuous improvement and mutual gains (Ostrom 1990; Weber 1998);

- mutual accountability mechanisms (Behn 2002);

- participant norms (North 1990);

- collaborative capacity building leadership (Weber \& Khademian 2008a; 2008b);

- credible commitment to collaboration (i.e., participants willingly direct their power and resources to cooperate in good faith toward mutually agreeable decisions and then to promote, protect, and enforce such deals (Daniels \& Walker 2001, 182; Weber 1998, 113 $115)$; and

- integrating and applying a broad knowledge base (Weber 2003).

However, in order to guard against the risk of overemphasising the local, it is imperative to bear in mind implications of wider global, national and regional political-economic contexts and processes highlighting the ongoing neo-liberalisation of natural resource governance, as these have contributed to profound changes in the way natural resources are managed (Jonas \& Bridge 2003). For this reason, a multi-scalar institutional analytical perspective provides a more realistic appraisal of barriers and ways to overcome them.

\section{ICM challenges in NZ}

Arguably, the RMA constitutes a logical planning framework for ICM, with the sole purpose of the Act defined in terms of sustainable management of natural and physical resources. Sixteen elected regional councils ${ }^{7}$, with administrative boundaries based on groups of large contiguous catchments, exercise a pivotal role for integrated resource management together with local district councils ${ }^{8}$. Yet, notwithstanding this, and in spite of growing public concerns about issues of water quality and quantity in the face of land use intensification and climate change implications, and notwithstanding a recent proliferation of an array of ICM type initiatives, our considered assessment is that ICM has not featured strongly in the way regional councils have interpreted and implemented their devolved RMA mandate relating to water management. Regional councils have prepared plans for water

\footnotetext{
${ }^{7}$ Including four unitary authorities which combine the functions of regional and district councils.

${ }^{8}$ The primary planning functions of district councils relate to land use regulation.
} 
allocation, water quality and land use on a primarily 'whole-of-administrative-region' basis, but few have prioritised water resource planning for water allocation and water quality at the catchment scale. Consequently, water resource planning tends to be more 'top-down' than 'bottom-up', with limited integration between allocation, quality and land use provisions on a specific catchment basis.

Based on analysis of a range of primary and secondary data sources for this study and related research on the implementation of the RMA since its enactment in 1991, including our own work, the challenges currently confronting ICM will be highlighted and discussed briefly below.

\section{Strategic spatial planning}

In the context of the RMA's devolved planning framework, a strategic spatial planning approach to water resource management at both regional and catchment scales is a key imperative to promote the sustainable management purpose of the Act via the integrated natural resource management function delegated to regional councils (Memon \& Skelton 2007). Most interviewees were in agreement that hitherto, the strategic and integrated attributes of planning have been generally lacking in regional council plan making and implementation practices.

What are the reasons for this policy lacuna? Ambiguity in the way the 'sustainable management' purpose of the Act is defined, and adoption of differing social constructions of the 'sustainable management' purpose of the RMA by regional councils, are considered key constraints to strategic planning by regional councils (Memon \& Skelton 2007). Most regional councils were compliant to a greater or lesser extent with the shift to the non-interventionist, free-market policy ideology promoted by central government between 1984 and 1999 and adopted in their regional plans a minimalist, reactive policy stance of 'light handed regulation' limited to managing adverse bio-physical environmental effects. Politically, provincial regional councils have been dominated by rural landowners and were reluctant to address water allocation conflicts or undertake rural land use regulation to address non-point source pollution (Memon \& Skelton 2007). It is only recently, following the 2005 amendments to the RMA, that regional councils have become cognisant of their strategic water planning role. The absence of strategic regional guidance that was strongly cognisant of the role of catchment based planning was perceived as an obstacle to ICM by study respondents in situations when catchment stakeholders do not agree on the problem or its severity (the need for action), or are satisfied with the status quo.

\section{Silo-mentality}


Related to the above, prevailing poor professional integration ('silo-mentality') within regional councils, between statutory and non-statutory planning, and natural science and social science components of plan making and implementation were identified as constraints by respondents. The professional collaboration proposition is emphasised in recent international literature (e.g., PahlWostl et al. 2008). Lack of integration of multi-disciplinary expertise, combined with the lack of opportunities to learn from other relevant processes were also considered to be key constraints in linking voluntary ICM plans with statutory regional plans. Ideally, ICM plans should have a statutory backing. However, it was clear from the respondents and other relevant sources (e.g., Edgar 2004) that there is not an ideal statutory/non-statutory combination that fits all catchments. As different processes and levels of rigour are required for different combinations of statutory and non-statutory planning, the decision on which approach to adopt needs to be made early in the ICM process.

\section{Lack of regional council support for ICM}

ICM initiatives to date in New Zealand tend to be ad hoc, reliant on availability of funding and personal initiative (Table 1). Several interviewees highlighted the limited staff and other resources allocated to catchment initiatives by regional councils. They noted the limited staff and other resources allocated to catchment initiatives, even where the political support for ICM was strong. Respondents placed particular emphasis on the need to fund good facilitators to steer the process.

Funding for planning at the catchment scale is a constraint for many regional councils, particularly those who don't have access to revenue from sources other than land taxes (e.g., shares in regional council owned port companies). Councils have accorded much higher priority to completion of their first generation statutory planning instruments (regional policy statements and plans) compared to catchment initiatives. Many catchment initiatives that have been implemented seem to have a limited shelf life and do not address highly contested issues such as water allocation. Links to statutory regional water plan provisions are also unclear. Central government has contributed to this situation through a failure to build capacity and commitment within the local government sector in order to exercise the devolved RMA water mandate (see below).

A respondent noted that regional councils are in an excellent position to drive the ICM process, as they are equipped with the necessary resources, technical support and permanency of staff. However, the respondent was unable to identify many good examples of it working, instead stating that "there has never been a real groundswell to say 'Even though we're based around catchment boundaries, we really are going to use... [catchments] as a framework to drive our natural resource management"” (Respondent 11)). 
Table 1: Examples of recent ICM-type initiatives in the South Island, New Zealand

1. Research to identify local resource management issues by a Royal Society Fellow which led to community meetings and field trips, an action plan and implementation via a sub-committee (Orari catchment).

2. The establishment of a statutory board to develop a Water Allocation Framework for the catchment (MfE 2005), and the appointment of a Panel of Commissioners to act as the consent authority (Waitaki catchment).

3. A community strategy co-ordinated by a community trust, a Participatory Action Research approach (e.g., Whyte et al. 1991), and the formation of a statutory agency managers group (multiple Lake Ellesmere catchment initiatives).

4. A community health $\mathrm{PhD}$ research project that resulted in the formation of a community trust, collaboration between the local university, regional council and community, and development of an integrated education resource (Taieri catchment). Among other measures of success, this initiative was awarded a "Green Ribbon Award" from the Ministry for the Environment in 2003 and an Otago Regional Council 'Environment Award'.

5. A government funded research partnership in which researchers, community and sector group stakeholders, and local government worked collaboratively on catchment-scale resource management issues (Fenemor et al. 2008). Initiatives included a Sediment Learning Group, a technical working group, on-line discussion groups, an Arts Science Project and an integrated modelling framework for testing future scenarios at catchment scales (Motueka catchment).

\section{Lack of support and capacity building by central government}

Even though central government has significantly devolved water resource management responsibilities to local government, it has provided limited policy guidance or direct support to build local capacity and political commitment. A recent review of ICM projects in the South Island of NZ (Edgar 2004) showed that catchment level projects often did not continue long enough or with sufficient funding to ensure that successes in particular areas were able to be built on and integrated, either horizontally (between catchments) or vertically (from the individual through to the national level). Central government support for local government is considered by respondents to be more critical than ever, as water resource issues outstrip planning and technical capabilities of regional councils. This lack of sustained resourcing was regarded by several interviewees as a critical constraint on effective community engagement and stakeholder participation as a continuous process. 


\section{Clarification of Māori property rights}

A related national context issue pertaining to ICM in New Zealand is the role of Māori as Treaty partners with the Crown in management of natural resources such as water. As with the recent settlement of fishery quotas, Māori claim ownership of water resources under the terms of the Treaty of Waitangi negotiated between the Crown and Māori in 1840. This claim has yet to be lodged and adjudicated, and uncertainty in the minds of regional council officials and farmers about future access to water by non-Maori was considered a barrier to collaboration by some respondents.

\section{Institutional fragmentation}

There are two aspects to respondent concerns about institutional fragmentation: division of planning responsibilities between regional councils and territorial local authorities (district councils); and difficulties of collaboration with central government agencies on a 'whole-of-government' catchment basis.

Fragmentation of local government responsibilities under the RMA with respect to resource management at the catchment level was considered by respondents to be a significant ICM challenge. The key division of responsibility for water allocation and quality (regional council function) and land (a shared district and regional council function) is of particular importance. Customarily, even though they have the authority under the RMA, regional councils seem politically loathe to regulate rural land use to manage non-point source pollution as an unwarranted restriction of private property rights. Even though territorial local authorities have a major role under the RMA for land use regulation, for political reasons they once again deem rural land use regulation as unwarranted and are reluctant to co-operate with regional councils on this matter (see also Memon \& Skelton 2007).

Likewise, it was deemed important for central government agencies to work collaboratively with local government to address catchment wide issues.

\section{Information}

A constantly changing system with a wide range of time lags between inter-connected causes and effects introduces significant uncertainties into ICM, which can easily inhibit progress (e.g., Weible 2008). Uncertainty has been described in terms of ignorance, disagreement, precision, bias, scale, conceptualisation, assumptions, and accuracy (SSSS Committee 2009). Uncertainty is considered a key ICM challenge by some respondents as it is a significant component of other ICM challenges as well. It can affect whether stakeholders participate, the manner in which they participate, the ability of multiple institutions and disciplines to hold meaningful conversations, and the prioritisation of resourcing to reduce constraining uncertainties. 
In the eyes of some respondents, relevant and verifiable information, reported to an appropriate reading age and audience is considered essential to making progress in the presence of uncertainty. Respondents considered that a variety of initiatives were necessary to combat uncertainty through collaboration. These include research meetings, symposia, site visits, individual interviews, research update newsletters, websites, collaboration with related projects, educational resources, independent reviews, and art and cultural events.

\section{Participation}

Inclusive community participation is important for reasons of democratic legitimacy and practical considerations related to problem solving and decision implementation (e.g., Stiftel \& Scholz 2005). Traditional consultative local authority processes were considered by some respondents to be a backto-front way of working with the community, in that the initiative was identified first, and the participation sought second. If the councils were first able to establish a collaborative relationship with the community, then as issues arose the resolution process could be less contentious. However, successful examples utilising this approach were difficult to find and the reality of increasing scarcity of allocatable water across NZ suggests conflict resolution will be contentious. Instead, the presence of some sort of 'crisis', either real or perceived, was considered the most likely reason for an ICM type process to be publicly supported. A perception by some farmers that there is no current water 'crisis' in Canterbury ${ }^{9}$ was seen as a barrier to participation in recent initiatives, though other farmers chose to participate in order to have their say as well as keep an eye on what other groups were up to.

One of the most promising collaborative catchment initiatives for water users was considered by some respondents to be audited self management (ASM). This is the process by which certain responsibilities of regional councils under the Resource Management Act (RMA) are delegated to water user groups under agreed terms and audit processes (INZ 2008). ASM is being implemented or considered for implementation in the ICM focus catchments in different ways. In Tasman and Otago, water user groups have been set up to address situations where surface water resources are limited and rostering and rationing of water takes is required to ensure that environmental flow requirements are met. In Tasman, the ASM details are set out in the regional plan while in Otago the water user group was made a committee of the regional council with delegated powers. Further initiatives are underway in Otago, though the decision to make water user groups a committee of the regional council with delegated powers is under review. In Canterbury, ASM potential is being considered in a primarily surface water catchment (Orari) and a primarily groundwater catchment (Ellesmere).

\footnotetext{
${ }^{9}$ Some farmers and scientists argue that the problem is not one of water shortage but rather that water is available in the right place at the wrong time!
} 
With the size and complexity of the Ellesmere catchment, irrigation cluster groups have been set up at the sub-catchment scale with a super-cluster group at the catchment scale.

\section{An adversarial climate}

A further challenge articulated by many respondents is the treatment of science and other expertise in an adversarial manner. This is considered to be a key hindrance to actualizing the RMA intent of integrated management of air, water and land. A planning approach limited to managing environmental effects of individual consents in a first-in-first-served process has provided incentives for water permit applicants to contest regional council decisions in courts of law on veracity of expert evidence (Memon \& Skelton 2007). The lack of National Environmental Standards and a National Policy Statement on water has also encouraged such challenges and the lack of sufficiently robust water quality and quantity data in many catchments required for probative evidence has made it difficult for regional councils to defend their decisions.

\section{Leadership}

Some study respondents drew an interesting distinction between leadership and facilitation. It was deemed that leadership is required from all participants in an ICM process, as all are required to participate in a manner that considers the interests of the stakeholders they represent at the same time as the interests of the wider community. While leadership by senior regional council officials is considered highly significant to enable and support a culture conducive to ICM, long term ICM success was perceived to rely principally on community leadership.

Facilitation requires a person or persons with sufficient trust and respect from participants to keep the process moving forward. The lack of trained and resourced facilitators was regarded by ICM respondents as a significant barrier to effective stakeholder participation. The role of the facilitator was considered imperative to build a reputable profile, establish trust, organise events and access and share information. A number of ICM interviewees favoured facilitation by an outside body (such as the NZ Landcare Trust) instead of a regulatory authority in order to achieve measurable change. On the other hand, some interviewees found that recent process facilitation by regional council Resource Care staff was held in high regard by participating stakeholders.

\section{Enhancing the potential of integrated catchment management}

The interrogation of ICM practices in New Zealand from an institutional perspective raises a number of wider theoretical and policy implications. The research findings highlight that a multi-scalar perspective is imperative to assess barriers to ICM practices and how they may be overcome. Both the drivers of and barriers to ICM practices in New Zealand identified above range in scale from 
global and national to regional and sub-regional/local. Northern hemisphere demand for New Zealand's dairy products in a highly competitive global free trade setting has been the major driver of the trend towards land use intensification and growing demand for water. From a national perspective, the Resource Management Act, the primary planning statute, has been unable to internalise the downstream adverse environmental impacts consequent on land use intensification. Integrated catchment management practices of various shades have emerged during the last two decades to contain such adverse impacts. But the research findings indicate that several formal and informal institutional barriers, ranging from national to regional and local, constrain the potential of ICM initiatives.

Recent literature on designing institutional arrangements based on grass roots approaches to integrated management has a strong focus on understanding 'local' (e.g., catchment wide) institutional settings and interactions (e.g., see Weber 2003). Arguably, while it is valuable to have this perspective, it is also important to situate critically informed understandings of local institutional arrangements and barriers within larger multi-scalar contexts (Gibbs \& Jonas 2000; Mansfield 2005). A multi-scalar perspective helps to appreciate wider structural constraints on regional and local water governance dynamics, including ICM practices.

A multi-scalar perspective is also helpful in order to prescribe ways to address formal and informal institutional constraints on ICM practices. Thus, the situation in New Zealand is that while, on the one hand, international trade barriers have been removed by recent neo-conservative governments, the state has, at the same time, devolved primary responsibilities for natural resource management to regional councils. Since the enactment of the RMA in 1991, successive central governments have shied away from taking a lead role in promoting effective environmental management via national policies and national standards. They have also been slow to develop institutional capacity and political commitment amongst regional councils to effectively exercise their devolved RMA mandate of integrated management. Formal and informal institutional arrangements for water governance nationally, regionally and locally do not provide sufficient incentives for stakeholders to collaborate to resolve conflicts over water allocation, quality and land management.

The barriers to ICM identified in this paper can be addressed in a number of inter-related ways:

- International agencies such as the EU, New Zealand's major trading partner, could encourage the New Zealand government to take its environmental obligations more seriously because of possible risks of European consumer boycotts and the threat to New Zealand's 'clean-green' image. Likewise, the OECD, which periodically audits environmental performance of member countries, could pressure New Zealand government to take its international Treaty obligations pertaining to biodiversity and wetland protection more seriously. 
- A national water policy should take full cognisance of the significance of ICM as a means to achieve the sustainable water management purpose of the Act and the pivotal role of regional councils in this respect. A joint funding formula with regional councils to support ICM practices should be part of the national policy.

- The issue of Māori water entitlements and their constitutional role in water governance needs clarification. The recently negotiated agreement between the Tainui tribe and the Crown for the joint governance of the Waikato River may provide a potential role model for future water governance arrangements.

- Regional council planning instruments (regional policy statements and plans) should embrace a sub-regional ICM dimension as a key attribute of region-wide water strategies to address inter-related issues of water allocation, water quality and land use. ICM initiatives and practices should be linked to regional water plan strategic objectives and policies. This will enable top-down and bottom-up approaches to more easily complement each other.

- At the catchment scale, to the extent that certain enabling, antecedent conditions are in place, collaborative participatory ICM practices will be more likely to succeed. Ideally, appropriate enabling conditions include strong social capital (Putnam 2000), high cultural or belief homogeneity (Sabatier et al. 2005), an economy not dominated by extractive industries (Lubell 2005), and good scientific knowledge about the resource problems at issue (Lubell 2005; Sabatier et al. 2005; Weber 1998). If such conditions are not present, however, a specific pragmatic, strategic approach to early problem solving, a series of initiatives that focus participants on shared values, common ground, and collective benefits, and a series of specific leadership practices can help to facilitate the transition to a successful collaborative institution (North 2005; Weber \& Khademian 2008b; Weber 2009).

- Once the enabling conditions are in place, it is important to craft a network-based culture grounded in a credible, effective commitment to collaboration that increases the certainty that participants' stakes will be treated fairly and as legitimate claims within the broader context of sustainability goals. This requires facilitation from collaborative capacity builders (Weber \& Khademian 2008a) with a relevant set of skills, traits and reputation.

- Long term, measurable progress requires all stakeholder groups of place, interest and regulation to participate throughout ICM processes at a level that leads to mutual accountability for process outcomes. More progress is required in this area, in particular through finding participation incentives for those doing well out of the current system and offering participation opportunities for those struggling in the current system. 
- Monitoring of performance toward agreed catchment targets or within agreed tolerances requires regular reporting on a comprehensive, measurable, understandable and achievable set of performance indicators. Integrated indicators that hide subjective weightings should be avoided as these weightings change across a community and over time (e.g., Painter et al. 2007). The use of the internet with information designed to a reading age of 12 is recommended to encourage wide participation.

While the implementation time frame for some of the suggestions is long-term, others can be implemented sooner.

\section{Conclusions}

Prospects of threats to water security throughout the world make it imperative that a fundamental realignment of institutional arrangements occurs in order to promote sustainability. This recognition has led to a shift from an emphasis on water management to water governance, grounded in collective action involving independent in-stream and out-of stream users, authorities and wider community interests.

Our research findings highlight the imperative to strengthen formal and informal institutional arrangements at the grass- roots catchment scale to promote the sustainability objectives of the RMA. Arguably, this has been a lacuna in recent water management plans and practices of regional councils. Our study findings also demonstrate that it is important to situate critically informed understandings of local and regional institutional arrangements and barriers within larger multi-scalar contexts. Such a perspective reveals the significance of recognizing and addressing wider national and global structural constraints on regional and local water governance dynamics, including emergent ICM practices. Therefore, it is critical that a national water policy should encapsulate topdown and bottom-up governance strategies simultaneously. It remains to be seen to what extent the current government's water reform initiatives will succeed in this respect.

We hope our paper will stimulate further debate about proposed water reforms in New Zealand. .

\section{Acknowledgements}

Funding for this project was provided by the New Zealand government through the Foundation for Research, Science and Technology, particularly under contract LVLX0303. We are grateful to study respondents for giving us their time and to Hamish Rennie and Susan Tulloch for their comments on an earlier draft. The authors carry total responsibility for the contents of this publication. 


\section{References}

Behn, RD 2001, Rethinking Democratic Accountability. Washington, D.C.: Brookings Institution Press.

Bowden, W 2002, Integrated catchment management rediscovered: an essential tool for a new millennium, Paper presented at Manaaki Whenua Conference, Wellington.

Brand, R \& Kervonen, A 2007, 'The ecosystem of expertise: complementary knowledges for sustainable development', Sustainability: Science and Policy, vol. 3, no.1, pp. 21-31.

Bright, JC, Weir, JJ \& Ford, S 2008, Dynamic Allocation of Groundwater for Irrigation, Report No. C08081/1, Aqualinc Research Ltd, New Zealand.

Brueckner, M \& Horwitz, P 2005, 'The use of science in environmental policy: a case study of the Regional Forest Agreement process in Western Australia', Sustainability Science: Practice and Policy, vol. 1, no. 2, pp. 14-24.

Castree N 2008, 'Neoliberalising nature: the logics of deregulation and reregulation', Environment and Planning, vol. 20, pp 131-152.

Curtis, A 2000, 'Landcare: approaching the limits of voluntary action', Australasian Journal of Environmental Management, vol. 7, no. 1, pp. 19-27.

Daniels, SE \& GB Walker 2001, Working through environmental conflict: The collaborative learning approach. Westport, CT: Praeger.

Dovers, S 2001, Processes and institutions for resource and environmental management: Australian experiences. Canberra: Centre for Resource and Environmental Studies.

Edgar, N 2004, Integrated Catchment Management Project: Final Report for the Landcare Research Trust and the Ministry for the Environment, NZ Landcare Trust, Christchurch, NZ.

Environment Canterbury 2007a, Restorative Programme for Lowland Streams - Summary notes from Non-adversarial science workshop hosted by Environment Canterbury, viewed 11/7/08, http://www.selwyninfo.org/upload/File/SelwynHistoricInfo/HIP_Water_System.pdf.

Environment Canterbury 2007b, Canterbury, its people, its resources. Climate Change: An analysis of the policy considerations for climate change for the Review of the Canterbury Regional Policy Statement, R07/4, ISBN 1-86937-630-7. 
Environment Canterbury 2008a, Rakaia Selwyn Groundwater Zone - Final Decision, viewed 30/9/09, http://www.ecan.govt.nz/NR/rdonlyres/4509C8BC-D418-44D4-A868-44CFDBD34635/0/

RakaiaSelwynGroundwaterZoneFinalDecision12February2008web.pdf.

Environment Canterbury 2008b, Selwyn Waimakariri Groundwater Zone - Final Decision, viewed 30/3/09, http://www.ecan.govt.nz/NR/rdonlyres/8D5C610E-D16F-4E64-953C-CDD662C1DB3F/ 0/SelwynWaimakaririGroundwaterAllocationZoneFinalDecisionofCommissioners.PDF.

Environment Court 2005, Environment Court Decision on Lynton Dairy Ltd, C108/2005, viewed 15/3/08, http://www.ecan.govt.nz/NR/rdonlyres/1C697F62-161E-4A74-921EE163C47CB9F6/ 0/LyntonDairy.pdf.

Fenemor, AD, Deans, NA, Davie, TJ, Allen, W, Dymond, J, Kilvington, M, Phillips, C, Basher, L, Gillespie, P, Young, R, Sinner, J, Harmsworth, G, Atkinson, M, Smith, R 2008, Collaboration and Modelling - Tools for Integration in the Motueka HELP Catchment, Water South Africa, vol. 34 no. 4, pp. 448-455.

FoRST - Foundation for Research Science and Technology 2008, Portfolio Investment Strategy: Maintaining Environmental Integrity for Sustainable Resource Use, viewed 11/7/08, http://www.frst.govt.nz/files/Portfolio\%20Investment\%20Strategy\%20SRU.pdf.

Gibbs, D \& Jonas, AEG 2000, 'Governance and regulation in local environmental policy: the utility of a regime approach', Geoforum, vol. 31 no. 3, pp. 299-313.

Gray, T (ed.) 2005, Participatory Fisheries Governance, Springer, The Netherlands.

Gunderson, LH \& Holling, CS 2002, Panarchy: Understanding Transformations in Human and Natural Systems, Island Press, Washington, D.C..

Hanna, S, Folke, C \& Maler, K (eds) 1996, Rights to Nature: Ecological, Economic, Cultural, and Political Principles of Institutions for the Environment, Island Press, Washington, D.C..

INZ - Irrigation New Zealand 2008, Decision Support Systems for Audited Self Management: Opihi Catchment, Contract Report for Ministry for Environment, Project No. 2243, 168p.

IPCC - Intergovernmental Panel on Climate Change 2005, Guidance Notes for Lead Authors of the IPCC Fourth Assessment Report on Addressing Uncertainties, viewed 20/4/09, http://www.ipcc.ch/pdf/supporting-material/uncertainty-guidance-note.pdf.

Jonas, AEG \& Bridge, G 2003, Governing nature: the re-regulation of resources, land-use planning, and nature conservation. Social Science Quarterly, vol. 84 no. 4, pp. 958-962. 
Kates, RW, Clark, WC, Corell, R, Hall, JM, Jaeger, CC, Lowe, I, McCarthy, JJ, Schnellhuber, HJ, Bolin, B, Dickson, NM \& Faucheux, S 2001, '[Policy Forum: Environment and Development] Sustainability Science', Science, vol. 292 (April 27), pp. 641-42.

Kerr, GN \& Swaffield, SR 2007, Amenity Values of Spring Fed Streams and Rivers in Canterbury, New Zealand: A Methodological Exploration, AERU Research Report No. 298, Lincoln University, viewed 20/4/09, http://www.lincoln.ac.nz/story_images/3960_RR298_s12933.pdf.

Lovell, C, Mandondo, A \& Moriarty, P 2002, 'The question of scale in integrated natural resource management', Conservation Ecology, vol. 5, no.2, viewed 5/5/09, http://www.consecol.org/vol5/ iss $2 / \operatorname{art} 25 /$

Lubell, M 2005, 'Do Watershed Partnerships Enhance Beliefs Conducive to Collective Action?' In P. Sabatier, W. Focht, M. Lubell, Z. Trachtenberg, A. Vedlitz, and M. Matlock, eds., Swimming Upstream: Collaborative Approaches to Watershed Management. Cambridge, MA: MIT Press: 201232.

Mansfield, B 2005, 'Beyond rescaling: reintegrating the 'national' as a dimension of scalar relations', Progress in Human Geography, vol. 29, no. 4, pp. 458 - 473.

Memon, PA 1993, Keeping New Zealand green: recent environmental reforms, University of Otago Press, Dunedin.

Memon, PA \& Skelton, PR 2007, 'Institutional Arrangements \& Planning Practices to Allocate Freshwater Resources in New Zealand: A Way Forward', NZ Journal of Environmental Law, vol. 11, pp. 241-277.

Memon, PA \& Weber, E 2008, Collaborative Water Governance in New Zealand: Turning the Corner in the Canterbury Region?, paper presented at $14^{\text {th }}$ International Symposium on Society and Resource Management, University of Vermont, Vermont, USA, June 10-14, 2008.

MfE - Ministry for the Environment 2005, Waitaki Catchment Water Allocation Regional Plan, Ref. ME685, viewed 4/7/08, http://www.mfe.govt.nz/publications/water/waitaki-regional-plansep05/waitaki-regional-plan-sep05.pdf.

MfE - Ministry for the Environment 2006, Proposed National Environmental Standard for Water Measuring Devices: Discussion Document, viewed 11/7/08, http://www.mfe.govt.nz/publications/ water/proposed-nes-water-measuring-devices-nov06/proposed-nes-water-measuring-devicesnov06.pdf. 
Mitchell, B 2007, 'Integrated catchment management and MSPs: Pulling in different directions?' in Warner,J (ed.), Multistakeholder Platforms for Integrated Catchment Management, Ashgate, pp. 120.

NIWA 2007, Proceedings of 'Water Resources: Information Challenges in a Changing Environment', 6-7 June, 2007, Te Papa, Wellington.

North, DC 1990, Institutions, Institutional Change, and Economic Performance. Cambridge: Cambridge University Press.

North, DC 2005, Understanding the Process of Economic Change. Princeton, NJ: Princeton University Press.

Olsen, SB 2003, 'Frameworks and indicators for assessing progress in integrated coastal management initiatives', Ocean and Coastal Management, vol. 46, pp. 347-36.

Ostrom, E 1990, Governing the commons: The evolution of institutions for collective action, Cambridge University Press, Cambridge.

Pahl-Wostl, C, Kabat, P \& Moltgen, J (eds) 2008, Adaptive and Integrated Water Management: Coping with Complexity and Uncertainty, Springer, Berlin.

Painter, BDM \& Bright, JC 2006, 'Adaptive Management of Groundwater Allocation: A New Zealand Case Study', Proceedings of Adaptive Management of Water Resources, AWRA Summer Specialty Conference, Missoula, Montana, USA, June 26-28, 2006.

Painter, BDM, Memon, PA, \& Leymarie, A 2007, 'Analysis of Stakeholder Objectives to Support Integrated Water Management in Central Canterbury', Proceedings of "Water and Land", NZ Hydrological Society Annual Conference, 20th - 23rd November 2007, Rotorua, New Zealand, pp. $72-73$.

Painter, BDM \& Memon, PA 2008, 'Enhancing the potential of integrated water management in New Zealand through adaptive governance', in Adaptive and Integrated Water Management: Coping with Complexity and Uncertainty, Springer, Berlin, pp. 227-248.

Painter, B (forthcoming), Analysis of linkages between climatic conditions and a brown trout (Salmo trutta) fishery: A case study on the Lake Ellesmere catchment.

Parkes, M \& Panelli, R 2001, Integrating catchment ecosystems and community health: the value of Participatory Action Research, Ecosystem Health, vol. 7, no. 2, pp. 85-106. 
Paton, S, Curtis, A, McDonald, G \& Woods, M 2004, 'Regional natural resource management: is it sustainable?' Australasian Journal of Environmental Management, vol. 11 (December), pp. 259-266.

Putnam, R 2000, Bowling Alone: The Collapse and Revival of American Community. New York, NY: Simon and Schuster.

Rennie, H., J. Thomson, T.Tutua-Nathan 2000, Factors Facilitating and Inhibiting Section 33 Transfers to Iwi. Hamilton: Univ. of Waikato and Eclectic Energy.

Rydin, Y \& Pennington, M 2000, 'Public participation and local environmental planning: the collective action problem and the potential of social capital', Local Environment, vol. 5, no. 2, pp. 153-169.

Sabatier, P, W. Focht, M. Lubell, Z. Trachtenberg, A. Vedlitz, \& M. Matlock. Eds. 2005, Swimming Upstream: Collaborative Approaches to Watershed Management. Cambridge, MA: MIT Press.

Sick, D 2008, 'Social Contexts and Consequences of Institutional Change in Common-Pool Resource Management', Society and Natural Resources, vol. 21, no. 2, pp. 94-105.

SWALG - Selwyn Water Allocation Liaison Group 2007, Analysis of Stakeholder Objectives Relevant to Selwyn Catchment Water Management, viewed 12/7/08, www.selwyninfo.org.

SWALG - Selwyn Water Allocation Liaison Group (2008a), Transcription of Water Governance Forum discussion, 2/5/2008, NIWA, Christchurch, viewed 12/7/08, www.selwyninfo.org.

SSSS Committee 2009, Second Selwyn Science Symposium: Discussion Session Transcription and Summary, March 9\&10 2009, viewed 18/4/09, www.selwyninfo.org.

Stiftel, B, \& Scholz, JT 2005, 'Conclusions - the future of adaptive governance'. Chapter 22 In T. J. Scholz \& B. Stiftel (Eds.), Adaptive Governance and Water Conflict. Washington: Resources for the Future.

Ti Kouka Consulting 2008, Selwyn Water Allocation Liaison Group: Review of Stakeholder Participation, viewed 11/7/08, http://www.selwyninfo.org/upload/File/SWALG/SWALG\%20 Review\%20Report_Web.pdf.

Tipa, G \& Teirney, L 2006, A Cultural Health Index for Streams and Waterways: A tool for $\begin{array}{lllll}\text { nationwide } & \text { use. } & \text { MfE } & \text { Report } & \text { viewed }\end{array}$ 
http://www.mfe.govt.nz/publications/water/cultural-health-index-for-streamsand-waterways-techreport-apr06/cultural-health-index-for-streams-andwaterways-tech-report-apr06.pdf.

Tipa,. G \& Welch, R 2006, Comanagement of Natural Resources: Issues of Definition From an Indigenous Community Perspective The Journal of applied behavioral science,42(3), 373-379.

Verma, $\mathrm{N}$ (ed.) 2007, Institutions and Planning, Elsevier, Amsterdam.

Vos, JP, Bauknecht, D, \& Kemp, R (eds) 2006, Reflexive governance for sustainable development. Edward Elgar, Cheltenham.

Warner, J 2007, 'The beauty of the beast: Participation for integrated catchment management', in Warner, J (ed.) Multistakeholder Platforms for Integrated Catchment Management, Ashgate, Aldershot, pp. 1-20.

Weber, EP 1998, Pluralism by the Rules. Washington, DC: Georgetown University Press.

Weber, EP 2003, Bringing Society Back In. Grassroots Ecosystem Management, Accountability, and Sustainable Communities, The MIT Press, Cambridge, Mass..

Weber, EP 2009, 'Explaining Institutional Change in Tough Cases of Collaboration: 'Ideas' in the Blackfoot Watershed,' Public Administration Review, vol. 69 no. 2 (March/April), pp. 314-327.

Weber, EP \& Khademian, AM 2008a, 'Wicked Problems, Knowledge Challenges, and Collaborative Capacity Builders in Network Settings', Public Administration Review, vol. 68, no. 2, (March-April), pp. 334-349.

Weber, EP \& Khademian, AM 2008b, 'Managing Collaborative Processes: Common Practices, Uncommon Circumstances,' Administration and Society 40 (5): 431-464.

Weber, EP, Memon, PA \& Painter, BDM 2009 'Science, Society, and Water Resources in New Zealand: What's Really Holding up Resolution of the "Science Impasse" in Canterbury?' Paper presented at the European Association of Planning Schools Congress, 15-17 July, University of Liverpool, UK.

Weible, Christopher M. 2008. "Expert-based Information and Policy Subsystems: A Review and Synthesis," Policy Studies Journal 36 (4): 615-635.

WET - Waihora Ellesmere Trust 2007, Draft Proceedings of Waihora-Ellesmere Living Lake Symposium, Lincoln University, Canterbury, Oct 31 - Nov 3, 2007. 
Whyte, WF (ed.) 1991, Participatory Action Research, Sage Publications Inc., Newbury Park, California. 